\title{
A new leaf spot caused by Alternaria alternata on Swertia spp.
}

\section{L.B. YADAV* AND M.S. NEGI ${ }^{1}$}

Department of Plant Pathology, College of Agriculture, G.B. Pant University of Agriculture and Technology, Pantnagar U.S. NAGAR (UTTARAKHAND) INDIA

${ }^{1}$ Department of Agronomy, College of Agriculture, G.B. Pant University of Agriculture and Technology, Pantnagar U.S. NAGAR (UTTARAKHAND) INDIA

\section{ARITCLE INFO}

Received : 28.01 .2016

Accepted : 29.03.2016

KEY WORDS :

Leaf spot, Alternaria alternata, Swertia spp.

*Corresponding author:
How to view point the article : Yadav, L.B. and Negi, M.S. (2016). A new leaf spot caused by Alternaria alternata on Swertia spp. Internat. J. Plant Protec., 9(1) : 362-364. 